\title{
Nicotiana tabacum as an Experimental Host for the Study of Plant-Xylella fastidiosa Interactions
}

\author{
S. A. Lopes, D. M. Ribeiro, P. G. Roberto, and S. C. França, UNAERP, Dep. Biotecnologia Vegetal, Av. \\ Costábile Romano, 2201, Ribeirão Preto, SP; and J. M. Santos, FCAV, UNESP, Rod. Carlos Tonanni, Km 5, \\ Jaboticabal, SP, Brazil
}

\begin{abstract}
Lopes, S. A., Ribeiro, D. M., Roberto, P. G., França, S. C., and Santos, J. M. 2000. Nicotiana tabacum as an experimental host for the study of plant-Xylella fastidiosa interactions. Plant Dis. $84: 827-830$

Xylella fastidiosa causes citrus variegated chlorosis (CVC). Information generated from the $X$. fastidiosa genome project is being used to study the underlying mechanisms responsible for pathogenicity. However, the lack of an experimental host other than citrus to study plant $-X$. fastidiosa interaction has been an obstacle to accelerated progress in this area. We present here results of three experiments that demonstrated that tobacco could be an important experimental host for $X$. fastidiosa. All tobacco plants inoculated with a citrus strain of $X$. fastidiosa expressed unequivocal symptoms, consisting of orange leaf lesions, approximately 2 months after injection of the pathogen. CVC symptoms were observed in citrus 3 to 6 months after inoculation. The pathogen was readily detected in symptomatic tobacco plants by polymerase chain reaction (PCR) and phase contrast microscopy. In addition, $X$. fastidiosa was reisolated on agar plates in 4 of 10 plants. Scanning electron microscopy analysis of cross sections of stems and petioles revealed the presence of rod shaped bacteria restricted to the xylem of inoculated plants. The cell size was within the limit typical of $X$. fastidiosa.
\end{abstract}

Citrus variegated chlorosis disease (CVC), caused by the xylem limited bacterium Xylella fastidiosa, has become a major problem for Brazilian citrus producers. In the state of São Paulo, responsible in 1996 for $83 \%$ of the national citrus production, the disease was present in all citrus growing areas (1). Despite eradication efforts, the percentage of infected plants, with variable levels of severity, increased from $15.7 \%$ in 1994 to $34 \%$ in 1996 (1).

After $X$. fastidiosa was identified as the causal agent of CVC $(2,3)$ and three species of leafhopper were identified as vectors of the pathogen (7), pruning of symptomatic branches of infected trees to reduce inoculum sources, use of healthy stock material for planting, and application of insecticides to reduce vector populations in the field were adopted as control measures by growers. However, this has not impeded the rapid spread of the disease to new locations. This may indicate that not all growers implemented the control measures and/or that they are not totally effective.

Corresponding author: S. A. Lopes

E-mail: slopes@unaerp.br

Accepted for publication 9 May 2000.

Publication no. D-2000-0620-01R

(C) 2000 The American Phytopathological Society
It is becoming evident that only the understanding of the complex interactions vectors is likely to lead to procedures that would permit effective disease control. The information generated with the complete genome sequence of the citrus strain of $X$. fastidiosa (14) might contribute to this understanding, revealing important information on potential pathogenicity genes.

One of the difficulties faced by those studying potential pathogenicity genes in $X$. fastidiosa is the lack of a good experimental host. Even though citrus is the target of these research efforts, citrus plants have proved not to be appropriate, mainly due to the extended periods, from 6 months to 1 year, required for symptom expression in inoculated plants $(2,5,6)$. A plant species that more rapidly expresses external symptoms would represent a major step forward in this regard. We show here that tobacco plants inoculated with a citrus strain of $X$. fastidiosa induced unequivocal leaf symptoms significantly faster than citrus, demonstrating that tobacco may represent an important experimental host for the pathogen.

\section{MATERIAL AND METHODS}

$X$. fastidiosa strain and inoculum preparation. The strain used in this study was isolated from infected orange trees among the plant, pathogen, and insect
(Citrus sinensis cv. Lima) located on São José farm in Taquaritinga, SP. Leaf petioles and midribs were removed from symptomatic leaves, surface-sterilized in $70 \%$ ethanol for $1 \mathrm{~min}$ followed by $3 \mathrm{~min}$ in $1 \%$ sodium hypochlorite, and washed twice with sterile water. Approximately $0.4 \mathrm{~g}$ of tissue was macerated in $1 \mathrm{ml}$ of phosphatebuffered saline (PBS), plated on supplemented PW (SPW) agar (5), and incubated for 20 days at $28^{\circ} \mathrm{C}$. Individual colonies were transferred to $50 \mathrm{ml}$ of liquid SPW and incubated for 20 days for inoculum production. The inoculum consisted of liquid cultures containing $10^{8}$ to $10^{9}$ CFU/ml, estimated by 10 -fold serial dilution plating.

Plants and inoculation. Seeds of a native variety of Nicotiana tabacum (accession RP1) were sown on the commercial substrate Plantmax (Eucatex, Paulínia, SP). Thirty-day-old plantlets were transplanted to 0.5-liter pots containing a 3:1 mixture of sandy soil and decomposed cow manure, or to foam trays containing Plantmax. The plants were inoculated 30 and 45 days later by injecting $0.1 \mathrm{ml}$ of the inoculum or cell-free SPW medium through insulin needles at four locations at the base of each plant. Fourmonth-old citrus plants (cv. Caipira), grown in 3-liter pots containing the soil and manure mixture described above, were also included in the experiments. The Caipira cultivar, like most of the Brazilian sweet orange cultivars, is known to be susceptible to CVC and to express leaf symptoms under field and greenhouse conditions. The stems of these plants were pruned to approximately $15 \mathrm{~cm}$ above the ground 3 weeks before the first inoculation. The inoculum was injected at several locations just below the only branch left after pruning. All tobacco and citrus plants were watered twice a day and maintained in an insect-proof greenhouse throughout the experiments. A water pad cooling system maintained the greenhouse temperature below $32^{\circ} \mathrm{C}$. Three experiments were conducted, with inoculation dates of 10 and 25 November 1998 for the first, 26 February and 15 March 1999 for the second, and 30 April and 15 May 1999 for the third. 
Detection of $X$. fastidiosa in plant tissues. Sixty days after the second inoculation, stem segments, petioles, and leaf midribs of tobacco and citrus plants were removed, surface-sterilized, and macerated in $1 \mathrm{ml}$ of sterile PBS as described. The stems were removed only from the tobacco plants, 2 to $3 \mathrm{~cm}$ above the injection site. A sample of $100 \mu \mathrm{l}$ of the macerate was diluted 10- and 100-fold in PBS, plated on PW agar (4) and incubated at $28^{\circ} \mathrm{C}$ for 30 to 45 days. A sample of $500 \mu \mathrm{l}$ was centri- fuged for $2 \mathrm{~min}$ at $10,600 \times g$ in a microcentrifuge, washed in extraction buffer $(0.5$ M Tris, pH 8.2, $140 \mathrm{mM} \mathrm{NaCl}, 2 \%$ acid washed polyvinyl-pyrrolidone [PVP] 10,000, and $0.05 \%$ Tween 20), resuspended in 20 $\mu \mathrm{l}$ of Milli Q sterile water (Millipore Corp., Bedford, MA), and boiled for 10 min. Of this mixture, $5 \mu \mathrm{l}$ was added to 20 $\mu \mathrm{l}$ of the PCR master mix consisting of $1 \times$ reaction buffer (Amersham Pharmacia Biotech, Piscataway, NJ), $3.5 \mathrm{mM} \mathrm{MgCl}_{2}$, $0.1 \%$ Triton X100, $0.2 \mathrm{mM}$ of each dNTP,
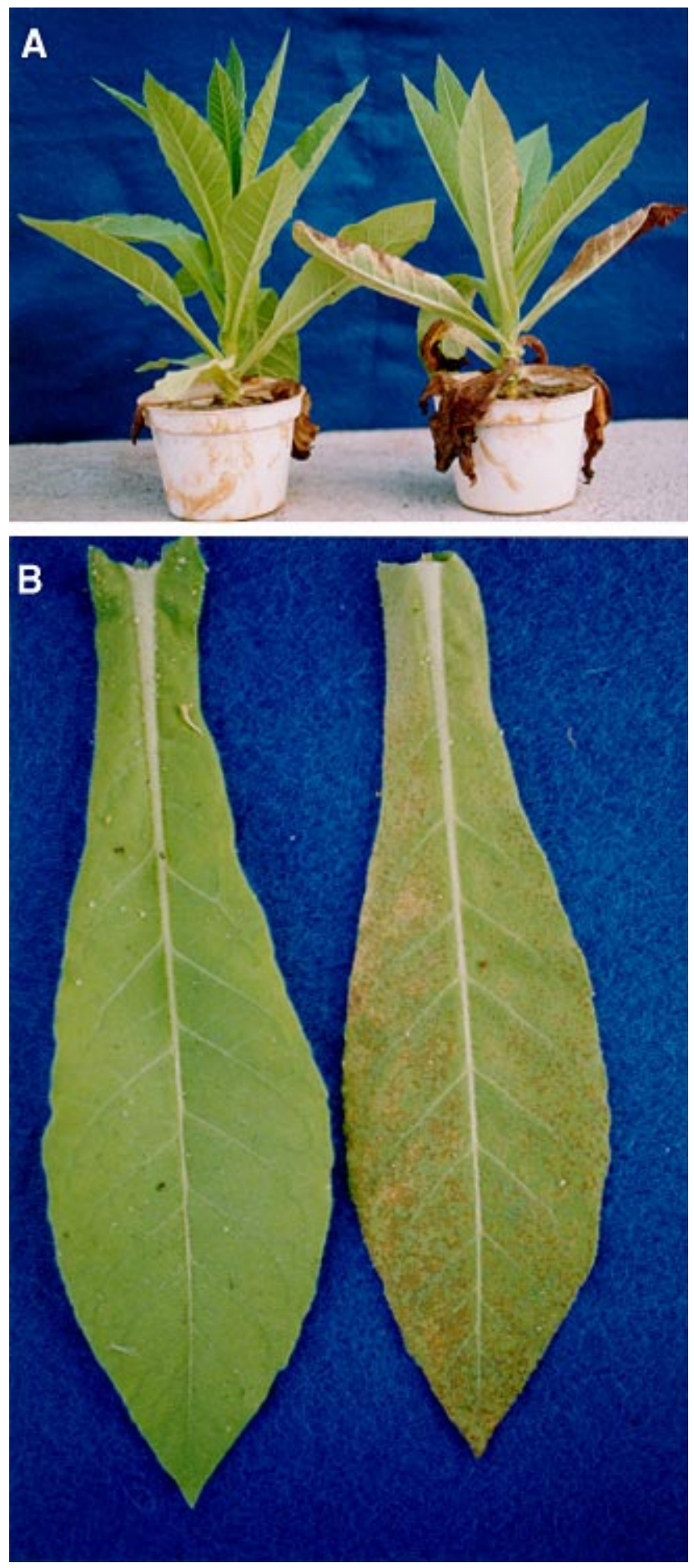

Fig. 1. (A) Tobacco (left) control and (right) inoculated with the citrus strain of Xylella fastidiosa 80 days after the second inoculation. (B) Detached leaves from the control and the symptomatic plant showing detail of leaf lesions.

1 unit of Taq DNA polymerase, and 12 pmols each of the primers XF5F (5'CAACGTGTAGCGCAAACG) and XF5R (5'-CGTCTGCTATTTATTGCATTTG).

This primer pair was designed based on a consensus sequence of the citrus strain of $X$. fastidiosa obtained in our lab as part of the sequencing work of the genome project. The primers showed high specificity for $X$. fastidiosa when tested against cell lysates of a diverse population of more than 50 nonidentified species of bacteria isolated from several plant species (8). PCR amplified products were separated in $1 \%$ agarose gels, stained with ethidium bromide, and photographed using standard procedures (10). PCR assays were conducted at least twice.

Cell observation using phase contrast and scanning electron microscopy. Cross and longitudinal sections of stems, petioles, and leaf midribs of symptomatic and control tobacco plants were prepared with a razor blade and observed under phase contrast and scanning electron microscopy (SEM). For phase contrast observations, cross sections of about $0.5 \mathrm{~mm}$ thick were mounted in water on glass slides and observed under Plan $10 \times$ and $40 \times$ objectives with a Eclipse E400 Nikon microscope (Nikon Corp., Tokyo, Japan). For SEM observations (13), sections about $1 \mathrm{~cm}$ long were fixed in $3 \%$ glutaraldehyde in $0.05 \mathrm{M}$ potassium phosphate buffer ( $\mathrm{pH} 7.4$ ) for 72 $\mathrm{h}$ at $5^{\circ} \mathrm{C}$, then rinsed with cold pure buffer and postfixed with buffered $2 \%$ osmium tetroxide for $12 \mathrm{~h}$ at $5^{\circ} \mathrm{C}$. The samples were rinsed again with the same buffer, then dehydrated with an eight-step graded series of ethanol during a 6 -h period at room temperature and dried at the criticalpoint with carbon dioxide. Cross and longitudinal sections of the dried samples were mounted onto stubs with adhesive copper tape on top. The edges of the tape were bordered with colloidal graphite. Finally, the samples were sputtered with gold-palladium and observed in a JEOL JSM 5410 SEM operated at $15 \mathrm{kV}$.

\section{RESULTS AND DISCUSSION}

On citrus, leaf chlorosis typical of CVC was detected in all 10 inoculated plants included in the first inoculation experiment, but in none of the controls (Table 1). The symptoms were first observed in three plants 80 days after the second inoculation. At this time, five plants, including those with symptoms, were positive when analyzed by PCR using the primer pair XF5F/XF5R. CVC symptoms continued to appear in the remaining plants until approximately 180 days after the second inoculation, when samples from all plants were PCR positive. Temporary symptom remission was observed in all plants from July to mid-October, which is in agreement with field observations. No citrus plants were included in the second experiment. In the third experiment, 5 months after the 
second inoculation, leaf chlorosis typical of CVC was observed in just one plant. The pathogen was isolated from the symptomatic and from one asymptomatic plant. Populations of viable $X$. fastidiosa cells were estimated in $2.1 \times 10^{5} \mathrm{CFU} / \mathrm{g}$ of petiole and midrib tissues of the symptomatic and $1.9 \times 10^{4} \mathrm{CFU} / \mathrm{g}$ of tissue of the asymptomatic plant.

On tobacco, all inoculated plants included in three experiments, but none of the controls, developed leaf symptoms (Fig. 1). The symptoms were characterized by small, dark orange lesions, appearing initially at the margins of the older leaves. The symptoms were detected first in a few plants around 6 weeks after the second inoculation, and 2 weeks later in all inoculated plants. Lesion coalescence resulted in burning of the older leaves, which was more severe on plants grown in the substrate Plantmax in foam trays than in the 3:1 mixture of sandy soil and cow manure. No visible damage was observed in the root system. Samples from all plants were PCR positive. Temporary seasonal symptom remission was not observed on tobacco plants.

Attempts were made to isolate $X$. fastidiosa from tobacco. The presence of fastgrowing contaminants did not allow detection of $X$. fastidiosa in any of the stem samples of the first and second experiments. In the third experiment, samples consisted of extracts of stems as well as petioles and midribs and were diluted 10and 100-fold before plating. In the first attempt, 60 days after the second inoculation, no colonies typical of $X$. fastidiosa grew on SPW. The plant stems were then allowed to regrow for another 60 days. The new branches showed leaf symptoms as described, and small colonies similar in color and shape to those isolated from symptomatic citrus were isolated from 4 out of 10 plants, in two attempts from petiole and midrib and in one attempt from stem samples. Consistently fewer contaminant bacteria grew on petiole and midrib samples than on stem samples. When cell lysates of the recovered bacteria and of known $X$. fastidiosa were tested by PCR with the primer pair XF5F/XF5R, a product of $490 \mathrm{bp}$ was amplified from all four samples and the positive control. Population of viable $X$. fastidiosa cells varied from $4.9 \times 10^{4}$ to $6.6 \times 10^{5} \mathrm{CFU} / \mathrm{g}$ of tobacco tissue.

Phase contrast and scanning electron microscopy (SEM) were also employed for pathogen detection in plant tissues. Under phase contrast microscopy, masses of bacterial cells could be observed streaming from the edge of the tissues. The masses of bacteria were more easily detected from stem than from leaf midrib cross sections, and after removing the epidermis and the layer of cortical cells that involves the plant vascular system. Careful analysis by SEM of stem cross sections revealed the presence of rod shaped cells, 0.45 to 2.82 $\mu \mathrm{m}$, inside many of the xylem vessels of symptomatic but not of control plants (Fig. 2). Cell shape and dimensions are consistent with those described for $X$. fastidiosa (15).

Lack of a good experimental host has been an obstacle for studies of plant $-X$. fastidiosa interactions. Hundreds of $X$. fastidiosa clones deficient or over-expressing pathogenicity genes are likely to be tested in order to carefully define the molecular basis of pathogenicity and viru- lence. Citrus plants require extended and variable periods before symptom expression $(2,5,6)$, as confirmed in this work. Symptom expression in citrus also seemed to be significantly influenced by temperature. Plants inoculated in November/December 1998 (spring/summer) required 80 days to 6 months to develop symptoms; whereas only one in six plants inoculated in April and May (fall) developed symptoms after 5 months. It is possible that the delay in symptom expression resulted from a reduction in multiplication rate of the pathogen caused by the lower temperatures registered in the greenhouse on 30 and 31 May, 2 and 22 to 25 June, and 9 and 10 August. The average lowest temperature on those days was $6.3^{\circ} \mathrm{C}$. Influence of low temperature on temporary symptom remission and bacterial recovery has been described for grapevine affected by $X$. fastidiosa $(11,12)$.

The results presented here indicate that tobacco, an experimental model plant for plant molecular biologists, could also be used as an experimental host for the study of pathogenicity genes in X. fastidiosa. The inoculated plants expressed symptoms faster than citrus, and temporary symptom

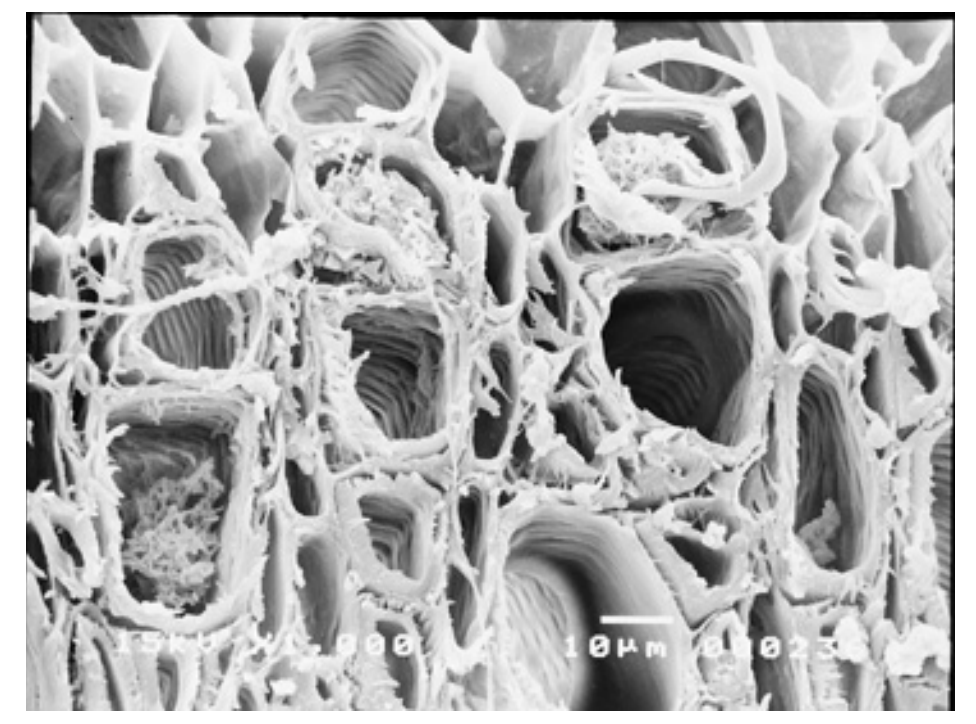

Fig. 2. Scanning electron micrograph of a cross section of a stem of symptomatic tobacco inoculated with the citrus strain of Xylella fastidiosa, showing masses of rod-shaped bacteria limited to the xylem vessels.

Table 1. Infection of citrus and tobacco plants artificially inoculated with the citrus strain of Xylella fastidiosa in three experiments conducted under greenhouse conditions

\begin{tabular}{|c|c|c|c|c|c|c|}
\hline \multirow[b]{2}{*}{ Experiment } & \multirow{2}{*}{$\begin{array}{c}\text { Inoculation } \\
\text { dates }\end{array}$} & \multirow[b]{2}{*}{ Treatment } & \multicolumn{2}{|c|}{ Citrus } & \multicolumn{2}{|c|}{ Tobacco } \\
\hline & & & Symptoms $^{\mathrm{a}}$ & $\mathbf{P C R}^{\mathbf{b}}$ & Symptoms $^{\mathrm{c}}$ & PCR \\
\hline First & $\begin{array}{l}10 \text { and } 25 \\
\text { Nov } 1998\end{array}$ & $\begin{array}{c}\text { Inoculated } \\
\text { Control }\end{array}$ & $\begin{array}{c}10 / 10 \\
0 / 10\end{array}$ & $\begin{array}{c}10 / 10 \\
0 / 10\end{array}$ & $\begin{array}{c}12 / 12 \\
0 / 10\end{array}$ & $\begin{array}{c}12 / 12 \\
0 / 10\end{array}$ \\
\hline Second & $\begin{array}{c}26 \mathrm{Feb} \text { and } \\
15 \mathrm{Mar} 1999\end{array}$ & $\begin{array}{c}\text { Inoculated } \\
\text { Control }\end{array}$ & $\begin{array}{l}\ldots^{\mathrm{d}} \\
\ldots\end{array}$ & $\begin{array}{l}\ldots \\
\ldots\end{array}$ & $\begin{array}{c}24 / 24 \\
0 / 24\end{array}$ & $\begin{array}{c}24 / 24 \\
0 / 24\end{array}$ \\
\hline Third & $\begin{array}{c}30 \text { Apr and } \\
15 \text { May } 1999\end{array}$ & $\begin{array}{c}\text { Inoculated } \\
\text { Control }\end{array}$ & $\begin{array}{l}1 / 6 \\
0 / 6\end{array}$ & $\begin{array}{l}1 / 6 \\
0 / 6\end{array}$ & $\begin{array}{c}10 / 10 \\
0 / 10\end{array}$ & $\begin{array}{c}10 / 10 \\
0 / 10\end{array}$ \\
\hline
\end{tabular}

\footnotetext{
${ }^{a}$ Chlorosis typical of citrus variegated chlorosis disease present in several leaves 6 month after the second inoculation.

${ }^{b}$ Polymerase chain reaction based on amplification of a 490-bp DNA segment using the primer pair XF5F/XF5R.

${ }^{c}$ Orange leaf lesions progressing to leaf burning first observed approximately 6 weeks after the second inoculation.

${ }^{\mathrm{d}}$ Not tested.
} 
remission was not observed. The pathogen was detected by PCR, isolation, phase contrast, and scanning electron microscopy, 2 to $3 \mathrm{~cm}$ above the site of inoculation in the stem and in the leaf petiole and midribs, indicating that the bacteria were able to colonize the plant tissues. Plant colonization and symptom expression were confirmed in another inoculation experiment (results not shown) using the strain 9 a5c of $X$. fastidiosa, which was originally isolated in 1992 from a CVC-affected Valencia orange tree (3). Strain 9a5c was isolated on BCYE agar plates (16) from stems of symptomatic tobacco, above and below the inoculation site, including the root system. Also, the pathogen was detected in macerated tissues by double antibody sandwich-enzyme-linked immunosorbent assay (DAS-ELISA) using commercial polyclonal antibodies (Sanofi Pasteur, France) produced against the citrus strain of $X$. fastidiosa.

The tobacco presented here as a new host for the citrus strain of $X$. fastidiosa consists of a native variety of $N$. tabacum not used for commercial planting. It was the only host that presented high susceptibility among more than 20 plant species investigated (9). The susceptibility was not limited to the citrus pathogen. Preliminary results indicate that the strains that affect Brazilian coffee and plum crops can also colonize the xylem and induce leaf symptoms in tobacco. This finding may open unique opportunities for comparative studies of distinct strains of $X$. fastidiosa. Tobacco susceptibility also may prove useful to study pathogen transmission by insects, allowing, for example, a more complete screening of potential vectors among the diverse populations of leafhoppers observed in crops of citrus, coffee, and plum.

\section{ACKNOWLEDGMENTS}

We thank Andrew J. G. Simpson from Ludwig Institute for Cancer Research, São Paulo, Brazil, for manuscript reviewing and helpful suggestions. This work was supported by grant 1997/6055-7 from the Fundação de Amparo à Pesquisa do Estado de São Paulo (FAPESP).

\section{LITERATURE CITED}

1. Amaro, A. A., Maia, M. L., and Gonzales, M. A. 1998. Economic effects originated from citrus variegated chlorosis. Pages 123-139 in: Citrus Variegated Chlorosis. L. C. Donadio and C. S. Moreira, eds. Est. Exp. Citricultura, Bebedouro, SP, Brazil.

2. Chang, C. J., Garnier, M., Zreik, L., Rossetti, V., and Bové, J. M. 1993. Citrus variegated chlorosis: Cultivation of the causal bacterium and experimental reproduction of the disease. Pages 294-300 in: Proc. Conf. Int. Org. Citrus Virol. 12th, New Delhi. Riverside, CA.

3. Chang, C. J., Garnier, M., Zreik, L., Rossetti, V., and Bové, J. M. 1993. Culture and serological detection of Xylella fastidiosa, the xylem-limited bacterium associated with citrus variegated chlorosis disease. Curr. Microbiol. 27:137-142.

4. Davis, M. J., Raju, B. C., Brlansky, R. H., Lee, R. F., Timmer, L. W., Norris, R. C., and McCoy, R. E. 1983. Periwinkle wilt bacterium: Axenic culture, pathogenicity, and relationships to other Gram-negative, xylem-inhabiting bacteria. Phytopathology 73:15101515.

5. Hartung J. S., Beretta, J., Brlansky, R. H., Spisso, J., and Lee, R. F. 1994. Citrus variegated chlorosis bacterium: Axenic culture, pathogenicity, and serological relationships with other strains of Xylella fastidiosa. Phytopathology 84:591-597.

6. Lee, R. F., Beretta, M. J. G., Hartung, J. H.,
Hooker, M. E., and Derrick, K. S. 1993. Citrus variegated chlorosis: Confirmation of a Xylella fastidiosa as the causal agent. Summa Phytopathol. 19:123-125.

7. Lopes, J. R. S., Beretta, M. J. G., Harakava, R., Almeida, R. P. P., Krügner, R., and Garcia, A., Jr. 1996. Confirmação da transmissão por cigarrinhas do agente causal da clorose variegada dos citros, Xylella fastidiosa. (Abstr.) Fitopatol. Bras. 21:343.

8. Lopes, S. A., Roberto, P. G., and França, S. C. 1999. Novos primers para a detecção da $X y$ lella fastidisa dos citros. (Abstr.) Fitopatol. Bras. 24:250.

9. Lopes, S. A., Roberto, P. G., and França, S. C. 1999. Hospedeiros alternativos da Xylella fastidiosa dos citros. (Abstr.) Fitopatol. Bras. 24:250.

10. Maniatis, T., Fritsch, E. F., and Sambrook, J. 1982. Molecular Cloning: A Laboratory Manual. Cold Spring Harbor Laboratory, Cold Spring Harbor, NY.

11. Purcell, A. H. 1977. Cold therapy of Pierce's disease of grapevines. Plant Dis. Rep. 61:514518.

12. Purcell, A. H. 1980. Environmental therapy for Pierce's disease of grapevines. Plant Dis. 64:388-390.

13. Santos, J. M., and Maia, A. S. 1997. A SEM improved technique for studying host-pathogen interactions of sedentary nematodes and for documentation of perineal patterns of Meloidogyne spp. Acta Microsc. 6:562-563 Suppl. B.

14. Simpson, A. J. G., and Perez, J. F. 1998 ONSA, the São Paulo Virtual Genomics Institute. Nature Biotechnol. 16:795-796.

15. Wells, J. M., Raju, B. C., Hung, H. Y., Weisburg, W. G., Mandelco-Paul, L., and Brenner, D. J. 1987. Xylella fastidiosa gen. nov. sp. nov: Gram-negative, xylem-limited, fastidious plant bacteria related to Xanthomonas spp. Int. J. Syst. Bacteriol. 37:136-143.

16. Wells, J. M., Raju, B. C., Nyland, G., and Lowe, S. K. 1981. Medium for isolation and growth of bacteria associated with plum leaf scald and phony peach diseases. Appl. Environ. Microbiol. 42:357-363. 